\title{
Preduvjeti za reformu Izbornog zakonodavstva u Bosni i Hercegovini
}

\author{
Goran Kovačević \\ Vanredni profesor Fakulteta za kriminalistiku \\ kriminologiju i sigurnosne studije Univerziteta u Sarajevu \\ gkovacevic@fkn.unsa.ba \\ Nedžad Korajlić \\ Redovni profesor Fakulteta za kriminalistiku \\ kriminologiju i sigurnosne studije Univerziteta u Sarajevu \\ nkorajlic@fkn.unsa.ba
}

\begin{abstract}
Sažetak: U radu se analizira specifična politička matrica nacionalne države uspostavljene na demokratskim principima. Pasivno i aktivno biračko pravo je temelj na kojem je izgrađena savremena (demokratska) država. Međutim, u Bosni i Hercegovini egzistira anomalija koju je vrlo teško dovesti u pravne okvire.

Većina država svijeta su nacionalne države gdje je nacija produkt određene političke ideologije, sa druge strane u BiH nacija/e su temeljene na organskim idejama kakva je religija gdje je politička praksa, odnosne, prozeletizam. Problem nastaje u činjenici da je demokratija ustvari, prije svega, kategorija emancipacije a tek onda pitanje prava i politike. Politika je zadnja o ovom nizu, ali u Bosni i Hercegovini postoji samo politika, emancipacija i pravo su shvaćeni kao produkti politike.

Autori, u radu, raspravljaju o posebnom političkom saglasju oko određenih društvenih kategorija koje će biti platforma budućeg izbornog zakona. Ovdje se predlaže ponovna uspostava redoslijeda: emancipacija, pravo i politika jer je to jedini način opstanka „organski“ heterogene društvene zajednice koja želi da živi u demokratskim okvirima.
\end{abstract}

Ključne riječi: reforma, izbori, sigurnost, politika, zakon, ideologija

\section{Uvod}

Jezik je kuća bitka. Činjenica da se razumijemo trebala bi biti osnova za rješavanje mnogih društvenih problema, od onih koji postoje među pojedincima do onih koji su dio kolektivne svijesti i pripadnosti. Ovo razumijevanje bi u normalnim uvjetima trebalo izroditi pozitivan zakonski okvir koji je usaglašen sa potrebama građana ove naše države. 
Unutar takvog zakonskog okvira izgrađuju se, sa jedne strane, institucije koje će voditi građane i davati im moduse zadovoljenja njihovih potreba $i$ ispunjenja njihovih ambicija. Sa druge strane uspostavljaju se i institucije čija je svrha da malom broju, onih koji ne razumije sadržaj jezičnih formulacija, na što bezbolniji način rastumače ispravnost ili neispravnost njihovog razumijevanja i na tome temeljenog djelovanja.

Ne postoji opće nerazumijevanje oko značenja riječi demokracija i kovanice nacionalna država. Problem nastaje kada se pod demokracijom pojavljuju surogati neprimjereni demokraciji: etnokratija, teoetnokratija, partiokratija i sl.. u takvom ambijentu partikularne svijesti koja se nastoji projicirati i prikazati kao kolektivna svijest dolazimo u probleme koji su nerješivi. Nastalo stanje se ne može nazivati političkom scenom već ratištem gdje je svaka zloupotreba dozvoljena i pohvaljena. Produkt ovakvih devijacija je intelektualni „,invaliditet“ na razini pojedinca o posljedicama vlastitih odluka i napravljenih izbora. Tako da od pojedinca ostaje skrivena jedna suštinska istina a to je da „odluke određuju sudbinu““.

Dok god je prethodno napisano istina bilo kakva reforma Izbornog zakonodavstva neće dovesti do pozitivnih promjena. Mnogo je drugih ,istina“ koje treba analizirati da bismo došli u poziciju i mogli se zabaviti formom koja će se koristiti u odabiru onih članova društva čija je zadaća da u ograničenom vremenskom periodu budu svijest i savjest, te tumači zelja, nadanja, snova, briga i strahova društvene zajednice čiju su izabrani prvaci. U nastavku ćemo analizirati ključna područja na koja se mora obratiti pažnja institucija upravljanja. O načinu na koji se riješe odnosna pitanja ovisit će i dobrobit bosanskohercegovačkog društva u narednim godinama.

Ključna područja su: sprječavanje da rat protiv terorizma bude destrukcija i izvor širenja opasnosti kao produkta zaoštravanja odnosa između muslimana i ostalih u Bosni i Hercegovini; promoviranje održivog razvoja kao pokretačkog principa politika u Bosni i Hercegovini; kreiranje pravila poštene i ravnopravne trgovine; poduzimanje potrebnih koraka u istrebljenju siromaštva, $i$ to putem oslobađanja od duga i dobrog vladanja. U svrhu ostvarivanja ovako ambicioznih ciljeva prethodno je potrebno unaprijediti kapacitet i promijeniti kulturu bosanskohercegovačkog društva, ono što je Robbie Robertson nazvao „potreba da se razvije novu svijest o sebi“ (2003 : 11), kako bi izbjeglo destabilizaciju i neželjene efekte ranijih talasa nacionalizma. Ovakav razvoj bio bi olakšan promoviranjem komponente demokracije - demokracije koja nije instrument nacionalizma, već instrument transmisije kozmopolitskih vrijednosti. Reforma zakonodavnih tijela je jedna od očitih potreba, jer 
nesposobnost odnosnih institucija da ostvare progres, nakon godina diskusija, je simptom problema na koji se treba obratiti pažnja, ili je etiketa ,zakonodavna vlast" samo dimna zavjesa iza koje utjecajni pojedinci ostvaruju svoje ciljeve (Bull, H. 1980 : 437-47). Winston Churchill-u se pripisuje rečenica: „Ljudi će na kraju uraditi ispravnu stvar, ali ne prije dok nisu probali sve ostalo“. Neograničeni kapaciteti vlade nude malo komfora kada kontempliramo o konotacijama nadolazeće krize. Imajući na umu Churchill-ove riječi, depresivno je prisjetiti se da je trebao rat da se etničke grupe tradicionalnog bosanskohercegovačkog društva „dogovore“ o višedimenzionalnim dejtonskim ,integracijama“. Izazov za nas je dokazati da Churchill nije bio u pravu i to odlučnim, brzim i dalekosežnim koracima konstruirati mreže upravljanja koje će donijeti organizacione i kulturne integracije, omogućavajući na taj način donošenje progresivnih odluka u kolektivnom interesu, kakva je i reforma Izbornog zakona.

U periodu koji dolazi, s aspekta političkog angažiranja, civilno društvo mora nastaviti da vrši pritisak na institucije države u odnosu na predstojeće aktivnosti, a ujedno ih i ohrabrivati da djeluju u zajedničkom interesu, prije negoli postane kasno. Posebna dužnost civilnog društva je ohrabrivanje vlada različitih nivoa u $\mathrm{BiH}$ da ujedine ciljeve i sredstva. Evidentno je nemoguće odmah iskorijeniti sve nesigurnosti koje su produkt nacionalizma, ali je odmah moguće uvesti i slijediti politike koje humaniziraju negativne efekte. Postizanje ovog cilja bilo bi lakše da je ostvaren progres u oblasti civiliziranja sistema državnog uređenja, uz razvoj demokratičnijih, ne temeljenih na nacionalnom ključu, državnih struktura.

Urlich Beck je u svojoj knjizi „Svjetsko društvo rizika“" predvidio da transnacionalni senzibilitet može biti nenamjerna posljedica posebno ekoloških kriza i da iz činjenice da prijetnja ne poznaje granice može nastati novi način razmišljanja. U prošlosti su nacionalna svijest i historija stvarale i sliku nacionalnih neprijatelja. Možda će i u budućnosti ostati ista situacija, ali Beck drži da će ljudi, u nadolazećem vremenu, iskusiti isti karakter sudbine ako ne dođe do potrebne evolucije svijesti. Prijetnje stvaraju društvo, globalne prijetnje stvaraju globalno društvo (Vonnegut, K. 2017 : 38-42). Mi smatramo da Bosna i Hercegovina ne smije biti definirana drugim dijelom Beckove opservacije i da jednom prestanemo projicirati sliku nacionalnih neprijatelja kao način osnaživanja predstava o veličini vlastite nacije.

Za nacionalistički mentalni sklop ideja višenacionalne države je oksimoron, i za mnoge je nezamisliva. Međutim, ista je situacija i sa ljudima srednjeg vijeka, i njima bi ideja nacionalne države izgledala kao oksimoron. 
Višenacionalna država u globalnom dobu, kao poveznica između mreža globalnog upravljanja iznad i proisteklih obveza ispod izazovan je i inspirativan novi pojam, ali ne takav koji bi bio privlačan nacionalistima. Prekratko je vrijeme da bi humano upravljanje moglo efektivno odgovoriti umnoženim izazovima krize odlučivanja, ali kraj Hladnog rata nas je podsjetio da nikada ne kažemo nikad. Ubrzano nestajanje svih ideoloških i materijalnih realnosti sovjetsko-američkog rata govori nam da sistematska transformacija ne može biti odbačena kao utopija. 80-ih godina prošlog stoljeća Hladni rat je postao suhoparan, a prijetnja nuklearnim ratom veoma izgledna mogućnost. Danas smo suočeni sa velikom krizom u kojoj su velike ideje dostigle svoje limite, a nesigurnost sve brže raste. Izazov ne može biti jasniji: da li će ova generacija političkih lidera koristiti predviđanja i razum da misle progresivno i konstruirati okvir za upravljanje u korist cijelog društva, ili će nastaviti kao da se ništa ne događa?

\section{Gdje smo to mi?}

Bez obzira na predviđanja o „kraju historije“ u zadnjem desetljeću 20. stoljeća, odgovori na velika pitanja politike, ekonomije i života nisu pronađeni. Religija se, naprimjer, vratila u velikom stilu na svjetsku scenu, nastavljajući balansiranje između svojih prozeletističkih sekti i borbe protiv sekularizma. Sigurno će se u budućnosti pojaviti još više ekonomskih ideologija koje će dovoditi u pitanje liberalno-kapitalistički model. Od svih predviđanja s kraja Hladnog rata, kao najlošija se pokazala pretpostavka da će ideološke borbe biti stvar prošlosti. Međutim, velika borba ideja nije završila kada je navodno završila Historija, pa tako možemo pretpostaviti da ideologija jednako nerazumnost i da u ovom novom dobu ideja ono što cvjeta jeste nerazumnost i reakcija, a ne sistem univerzalne emancipacije. Francis Wheen je simbolično datirao kraj 20. stoljeća 1979. godine, a ne u konvencionalnoj prekretnici 1989. ili 2001. godine. Prema Wheen-u, 1979. godina je obilježena dolaskom Margaret Thatcher na vlast i ponovno vraćanje viktorijanskih vrijednosti. U međuvremenu, Homeini u Iranu restaurira prethodni 1300-godišnji sustav (Kovačević, G. 2013: 49). Nemoguće je odbaciti ovu tvrdnju da je odnosna godina početna era kultova, gurua, iracionalne panike, predmodernista, postmodernista, srednjovjekovnih teokrata i mistika novog doba, te moralne konfuzije. Prostor novog doba ratova ideja je već bio dobro revitaliziran, čak i prije nego što je staro doba ideologija proglašeno završenim. Kao tipičan primjer nerazumnosti koja se pojavila, možemo uzeti niz 
bosanskohercegovačkih političara koji tvrde da su progresivni modernizatori i promicatelji obrazovanja, a koji brane kreacionizam (vjeronauka) u školama kao protutežu religijskom obrazovanju. Ovdje svakako treba kritizirati intelektualce koji su posvećeni prosvjetiteljskim vrijednostima, a u isto vrijeme neodlučni da ih brane iz straha da ne bi bili etiketirani kao liberalni imperijalisti (Abazović, M. 2008: 23).

Nedostatak razumijevanja, također, jedan od negativnih fenomena našeg vremena, sa nepredvidljivim posljedicama. Monstruoznosti su svuda oko nas: religijski fanatizam i utilarizam, politički ekstremizam, genocidne tendencije, terorizam, brutalnost i mržnja. Specifične instance odnosnog od početka 90-ih godina prošlog stoljeća uključuju vidljivo ludilo i genocid na Balkanu, u Ruandi, talibanske srednjovjekovne modalitete, radikalizam islamskog svijeta, brutalni hinduski nacionalizam, politiziranje religijskih prava u SAD, antisemitizam i stavove uperene protiv roma u Istočnoj Europi, oživljavanje populističkih desničarskih pokreta kao odgovora na migrantsku krizu i državno orkestrirano negiranje holokausta u Iranu. U ovakvoj situaciji ,sukob civilizacija“ mogao bi postati opasno proročanstvo koje samo sebe ispunjava, a ne samo kruta i osporiva znanstvena teorija.

Zanimljivo je kako religija još jednom zauzima centralno mjesto u politici. Primjera radi, sekularne politike u Bosni i Hercegovini su suočene sa sve više religijskim društvenim poretkom. Ključna dinamika koju vidimo ovdje je potencijalna sigurnosna dilema na relaciji razum-vjera, gdje se arapski stav da je Zapad prijetnja Islamu, a sa druge strane stav Zapada da je Islam prijetnja njegovim vrijednostima sve snažnije osjeća na teritoriji naše države. Kao što je to slučaj sa svim vrstama sigurnosnih dilema, u ovom specifičnom potencijalnom konfliktu opasnost će se povećati direktno proporcionalno nedostatku senzibiliteta o sigurnosnoj dilemi - nedostatak empatije za strahove jednih od drugih i razumijevanja uloge koju stavovi i ponašanja jedne strane igraju u gomilanju tih stavova kod druge strane i obratno. Bez sumnje „sukob civilizacija“ bi mogao biti ishod ovog stanja ako se dozvoli da nerazumnost pobijedi. Odnosni sukob najbolje je shvaćen u riječima Edward Said-a, i on ga ne smješta među civilizacije, nego ga naziva sukob neznanja (Said, E. The Nation, 12. 10. 2001) i vidi ga kao pogrešnu interpretaciju i sirovu reakciju na vjersko-religijsku sigurnosnu dilemu. Historija pokazuje da u situacijama gdje se religija počne uplitati u politiku za očekivati je probleme. Kada se religija nametne, kod ljudi postoji tendencija preuzimanja tradicionalnih uloga (ili im se one daju) u tradicionalnim i komfornim scenarijima, prije nego pristajanje uz nepredvidljivosti ishoda razumskog djelovanja. 
Danas nije neuobičajeno čuti da ljudi govore: kao muslimanu ili kršćaninu to mi jeste ili nije dozvoljeno. Ovakve prakse otkrivaju prije sklonost ka konverzaciji po određenom scenariju, a ne dijalogu u racionalnoj diskusiji, podrazumijevaju da se sluša al ne čuje, da se govori tekst iz knjiga koje ne mogu biti ponovo napisane a da se pri tome ne uništi priča koja daje smisao odnosnim praksama. Važno je naglasiti da u ovakvim slučajevima ljudi smatraju da je njihova uloga u ovim tradicionalnim pričama apsolutna i da im svi aspekti života moraju biti usklađeni s njom.

U uslovima religijsko-nacionalističke ideološke matrice, odnosno teoetnokratskog društvenog poretka postulati klasične demokratije ne mogu doći do izražaja. Shvaćanje čovjeka kao svjesnog bića sa različitim identitetima je svedeno na minimum. U ambijentu nepovjerenja i straha, koji se u BiH kreira četvrtinu stoljeća, gotovo je nemoguće opredmetiti projekte koji se temelje na povjerenju i moralu. Takav jedan projekt je i reforma Izbornog zakona usmjerena na čovjeka. Demokratija daje mogućnost pojedincu da se ostvari u punom kapacitetu, neovisno o identitetskom predznaku koji mu se dopisuje kao pravna činjenica. Surogati demokratije ne prepoznaju čovjeka, već pripadnika nacionalne, etničke ili religijske grupe - što je kod nas jedno te isto.

Ovdje je još potrebno spomenuti još jedan fenomen, i to upravo onaj čiji eho dolazi iz perioda između dva svjetska rata. Radi se o mogućnosti da je u našem društvu već posijana klica fašizama. Fašizam je kontroverzan pojam, i oni koji prihvate argumente koje smo do sada navodili, vjerojatno će i ovdje imati razumijevanja. Ovu svoju tvrdnju pokušat ćemo ukratko opravdati, ali prije toga želimo iznijeti jednu ne tako tendencioznu tvrdnju i to da nije moguće garantirati donošenje mudrih odluka u situaciji kada splet prijetnji zaguši društvo (Janis, I. L. 1972 : 19).

Fašizam je potreban okidač, a prethodna diskusije upućuje na veliki broj mogućnosti koje proizlaze iz stjecišta političkih, društvenih, ekonomskih i ekoloških izazova. Da sada je bilo bezbroj upozorenja o nadolazećim opasnostima po čovječanstvo i globalno i lokalno, ali oni najmoćniji i najbogatiji u svijetu ne žele radikalne promjene, u krajnjem slučaju ne znaju kako ih izvesti, dok mnogi misle da za tim još nema potrebe. Da li je pogrešno pretpostaviti da bi bilo bolje - mora prvo biti još gore i da ovdje postoji prostor za rast ekstremizma. Iz seta fenomena koje smo već naveli, moguće je identificirati dijapazon specifičnih problema koji bi se mogli kombinirati u jednu jasnu situaciju povoljnu za ekstremizam. Dakle, ovdje su uključene moguće posljedice masovnih migracija i glad i društveni stres nastao iz pritiska života u višenacionalnom društvu i društvene beskrupuloznosti proistekle 
iz epohe uspostavljenih društvenih i religijskih vjerovanja. Kada negativni efekti spontano konvergiraju u jednu točku, mogle bi se rasplamsati strasti kod većine populacije, hranjene rastom anksioznosti od posljedica straha od bolesti i stranih običaja, straha da će se biti pometeno od ljudi koji su etnički i rasno drugačiji.

U ovakvoj situaciji tradicionalna populacija će izgubiti povjerenje u uspostavljene institucije, jer se osjeća bespomoćno i nesigurno u svoju budućnost. Ako bi ovakve okolnosti nastupile, neminovna posljedica jeste ekonomski kolaps, što jeste jak okidač za rast fašističkih vrijednosti, osobito što sve više ljudi strahuje za radna mjesta i sigurnost, dok se kod njih pojačava osjećaj da nemaju koristi od svakodnevne politike. U uvjetima koje smo skicirali nije teško razumjeti da se zbunjeni i prestravljeni ljudi okreću karizmatičnim vođama. U krizama, obećanja davanja odgovora, sigurnosti i nade je primamljivo. Za očekivati je pojavu grupa i pojedinaca koji bi mogli iskoristiti ovu situaciju i manipulirati voljnim ljudima. Ne možemo zaboraviti da sve ovo brzo može skončati u ekstremizmu. Brzi uspon Hitlera 1932./1933. godine, odmah nakon očiglednog pada njegovog pokreta samo deceniju ranije, dobar je podsjetnik kako se situacija brzo može promijeniti, i kako nešto što se danas čini nemogućim već iduće godine bude moguće (Ress, L 1997 : 13-85). Upravo je u Europi 30-ih godina samozadovoljstvo dobrih i umjerenih građana nesvjesno doprinijelo porastu ekstremizma i to ponovo može biti slučaj, ali ne samo u Europi. Ekstremisti to znaju. Tako je John Gray objasnio kako je Nick Griffin, vođa jedne ekstremno desne partije u Velikoj Britaniji, smatrao da je u to vrijeme prava prilika da se ponovo uspostavi bjelačka dominacija, prilika kakve nije bilo 200 godina (Guardian, 28. 10. 2016).

Smatramo da je fašizam predodređen da se revitalizira ako se ne reagira na vrijeme na predvidljive nesigurnosti u Bosni i Hercegovini. Naravno, ne mislimo da će se pojaviti kolone novih Hitler-a i Mussolini-ja, jer je simbolika i naslijeđe presnažno za bilo kakvu ozbiljnu uporabu ovog termina. Upravo zbog totalne diskreditacije fašizma poslije 1945. godine, i činjenice da mnogi ljudi svakodnevno koriste ovaj termin u različite svrhe opisujući neku lošu osobinu, političke grupe su oprezne u identificiranju sa ovim terminom. Međutim, prije 1945. godine, fašizam je imao mnogo preciznije značenje, iako je njegova manifestacija u različitim državama poprimila lokalnu formu. Ako uzmemo da je fašizam općenito sinonim za desno orijentirani autoritarni ekstremizam, onda je moguće identificirati širok spektar pojava koje sadrže suštinu fašizma kao seta političkih ideja (Paxton, R. O. 2005 : 221-49). 
Fašizam može biti definiran u nekoliko generičkih pojmova: leadership (autoritet karizmatičnog vođe centralna osobina svih fašističkih pokreta); prometanje države (mistika nacije, pojedinci žive za državu, ali ne i obratno; fašisti su privučeni komunitarnoj, u pravilu, mitskoj prošlosti; gotovo da postoji religijska žudnja za jedinstvom naroda); politički modalitet (fašistički pokreti sebe vide kao revolucionarne, nastojeći da pomlade svoje društvo; fleksibilni su ideološki i u praksi; spolja su konzervativni u važnim segmentima - priznaju autoritet vjerskih institucija i određenih klasa, ali su modernisti s aspekta tehnologije i imaju izražene totalitarne impulse u izražavanju svojih vrijednosti cijelom društvu; organizaciono fašisti su antidemokratski i autoritarni, a u ponašanju netolerantni i usmjereni na akciju); društvene vrijednosti (fašističko društvo karakterizira patrijarhat, rasistički stavovi i politike; vrjednovanje lojalnosti; fascinacija zastavama, uniformama i drugim upakovanim identitetima; shvaćanje da nasilje ima ulogu iskupljenja); vanjska politika (na vanjskom planu fašisti su agresivni, imperijalisti, militaristi i ekspanzionisti ako je moguće; moć i sila su poruka, a često i sredstvo); ekonomska politika (fašistički pokreti imaju neke socijalističke akreditive, jer su antikapitalistički, barem retorički dok su u praksi duboko involvirani u velike poslove, spajanje država, industrijskih carstava i profesionalnih klasa); generalni pogled na svijet (fašizam je privučen mikro idejama, dok se protivi idejama koje promoviraju univerzalne ideje kao što su čovječanstvo i sl., razum se odbacuje zarad mišljenja krvlju i sl.).

Put pred nama nije lagan. Možda neko misli da je reforma Izbornog zakona samo formalno pitanje, ali mi vas uvjeravamo da je to pitanje suštine, na koju smo pokušali prethodno ukazati. Reforma koja je potrebna je znatno složenija i dugotrajnija i, bez pomoći prijateljskih naroda Europske Unije gotovo ne izvediva u Bosni i Hercegovini. Ljudi koji su u prilici da upravljaju resursima u našoj državi se neće odreći pozicija bez da, prije toga, društvo ne uvedu u novi rat.

\section{Zaključak}

Svaki čovjek na neki način ima svijest o boljem i može prepoznati moduse koji stvarno vode ka tom nekom napretku, u konačnici koji vode većem nivou sigurnosti društva u kojem pojedinac živi i razvija se. Međutim, da bi se ta svijest materijalizirala pojedinac mora pokloniti vjeru vrlo nedorečenim konceptima čiji je jedini argument moralnost $\mathrm{i}$ integritet pojedinaca koji ih propagiraju. Demokratija sa svim svojim institutima, dakle i formom izbora 
predstavnika, je jedan takav koncept. Naviknutost na neprimjerene surogate demokratije koji su instalirani kao mehanizam uspostavljanja državno - društvenog uređenja pojedincu zamagljuje sve mogućnosti koje pred njim postoje. Dodatno, tog hipotetičkog pojedinca odbijaju od promjena i argumenti i dokazi koji se predočavaju u ime surogata. Sve su to dokazi historije izvučeni iz konteksta, dokazi krvi i dokazi straha. Ustvari svijest zahtjeva razumijevanja da su upravo surogati i njihovi propagatori bili glavni nosioci fabriciranja historijskog narativa i glavni akteri u nastajanju dokaza krvi i proizvodnji straha, da su baš ti stvorili abmijent i povoljne uslove za uspostavljanje svoje vlasti i neviđeno bogaćenje svojih lojalnih i odanih sljedbenika i da su i da će biti veoma agresivni u cemetiranju tih svojih pozicija. Ovaj naš pojedinac rješenje vidi u odlasku u strana društva gdje nema problema da razumije demokratske okvire u kojima ti stranci funkcioniraju i čak da prihvati elemente njihovog kolektivnog identiteta koji su identični onima u njegovoj državi i kojih se užasavao sve dok ju nije napustio. Moglo bi se ovdje pisati naširoko i o građanskom nacionalizmu tih odredišnih država, uspostavi nacije kao političke a ne organske kategorije, ali mislimo da je čitaocu već dosada jasno šta je suštinski problem. Dok god nama Bosancima i Hercegovcima, Bošnjacima, Srbima i Hrvatima, te pokojem ostalom, ne bude jasno da su nam okovi oko vrata i da ništa ne možemo izgubiti skidanjem tih okova osim samih okova, reforma izbornog zakona će biti u službi osnaženja pozicija fašističkih političkih subjekata a ne demokratizacije i oslobađanja društva.

\section{Literatura}

Edward W. Said, 'The Clash of Ignorance', The Nation, 22 October 2001.

Francis Wheen, How Mumbo-Jumbo Conquered The World. A Short History of Modern Delusions (London: Fourth Estate, 2004).

Goran Kovačević, Mirza Smajić, Jasmin Ahić, Nedžad Korajlić, Novi koncept razumijevanja odnosa sigurnosti i politike, Policija i sigurnost, godina 22. broj 2/2013. MUP HR, Hrvatska, str. 236 - 248., 2013.

Hedley Bull, 'The Great Irresponsibles? The United States, the Soviet Union, and World Order', International Journal, vol. 25, 1980.

Irving L. Janis, Victims of Groupthink. A Psychological Study of Foreign Policy Decisions and Fiascos (Boston: Houghton Mifflin, 1972).

John Gray, 'Apocalypse Soon', The Guardian, 28 October 2016.

Kovačević, Goran, Alispahić, Bakir, Abazović, Mirsad, Bezdrob, Enes, Ekološka sigurnost, (Sarajevo, FKKSS, 2016.).

Kurt Vonnegut, A Man without a Country (London: Bloomsbury, 2017).

Laurence Rees, The Nazis. A Warning from History (London: BBC Books, 1997).

Mirsad D. Abazović, Ogledi o bosanskohercegovačkoj stvarnosti (Sarajevo, FKN, 2008.) 
Robbie Robertson, The Three Waves of Globalization. A History of a Developing Global Consciousness (London: Zed Books, 2003).

Robert O. Paxton, The Anatomy of Fascism (London: Penguin, 2005).

Urlich Beck, Risk Society (London, SAGE Publications, 2003).

\section{Prerequisites for Election Legislation Reform in Bosnia and Herzegovina}

\section{Summary}

The paper analyzes the specific political matrix of the national state established on democratic principles. Passive and active voting right is the foundation on which a modern (democratic) state is built. However, there is an anomaly in Bosnia and Herzegovina that is very difficult to integrate into the legal framework.

Most countries in the world are national states where the nation is the product of a certain political ideology, on the other hand in $\mathrm{BiH}$ nations are based on organic ideas such as religion - where the political practice is proselytism. The problem arises from the fact that democracy is in fact, first of all, a category of emancipation and only then a question of law and politics. Politics is in the last place in this line, but in Bosnia and Herzegovina there is only politics emancipation and law are understood as products of politics.

In this paper, the authors discuss a specific political consensus on certain social categories that will be the platform of the future election law. It is proposed to re-establish the order: emancipation, law and politics, because it is the only way for the survival of the "organic" heterogeneous social community that wants to live in a democratic framework.

Keywords: Reform, Elections, security, politics, law, ideology 